NBER WORKING PAPER SERIES

\title{
DOES TELEVISION KILL YOUR SEX LIFE? MICROECONOMETRIC EVIDENCE FROM 80 COUNTRIES
}

\author{
Adrienne Lucas \\ Nicholas Wilson \\ Working Paper 24882 \\ http://www.nber.org/papers/w24882 \\ NATIONAL BUREAU OF ECONOMIC RESEARCH \\ 1050 Massachusetts Avenue \\ Cambridge, MA 02138 \\ August 2018, Revised June 2019
}

Florin Feier and Samantha Sweeney provided excellent research assistance. The findings, interpretations, and conclusions expressed in this paper are those of the authors and do not necessarily represent the views of the aforementioned individuals or agencies, nor of the National Bureau of Economic Research. All errors are those of the authors.

NBER working papers are circulated for discussion and comment purposes. They have not been peer-reviewed or been subject to the review by the NBER Board of Directors that accompanies official NBER publications.

(C) 2018 by Adrienne Lucas and Nicholas Wilson. All rights reserved. Short sections of text, not to exceed two paragraphs, may be quoted without explicit permission provided that full credit, including $(\odot$ notice, is given to the source. 
Does Television Kill Your Sex Life? Microeconometric Evidence from 80 Countries

Adrienne Lucas and Nicholas Wilson

NBER Working Paper No. 24882

August 2018, Revised June 2019

JEL No. I12,I31,J13

\begin{abstract}
$\underline{\text { ABSTRACT }}$
The canonical consumer demand model predicts that as the price of a substitute decreases, quantity demanded for a good decreases. In the case of demand for sexual activity and availability of alternative leisure activities, popular culture expresses this prediction as "television kills your sex life." This paper examines the association between television ownership and coital frequency using data from nearly 4 million individuals in national household surveys in 80 countries from 5 continents. The results suggest that while television may not kill your sex life, it is associated with some sex life morbidity. Under our most conservative estimate, we find that television ownership is associated with approximately a $6 \%$ reduction in the likelihood of having had sex in the past week, consistent with a small degree of substitutability between television viewing and sexual activity. Household wealth and reproductive health knowledge do not appear to be driving this association.
\end{abstract}

Adrienne Lucas

Lerner College of Business and Economics

University of Delaware

419 Purnell Hall

Newark, DE 19716

and NBER

alucas@udel.edu

Nicholas Wilson

Department of Economics

Reed College

3203 SE Woodstock Blvd

Portland, OR 97202

nwilson@reed.edu 
"Don't think that I am saying this in a lighter vein. I am serious. TV will have a great impact. It's a great medium to tackle the problem . . . 80 per cent of population growth can be reduced through TV." - Ghulam Nabi Azad, India Health and Family Welfare Minister (Blakely 2009)

"No TV in the bedroom. I've always assumed it would completely kill my sex life and sense of intimacy.” - Jessica Herman, Journalist, Cosmopolitan (Herman 2013)

\section{Introduction}

The canonical consumer demand model predicts that as the price of a substitute decreases quantity demanded for a good decreases. In the case of sexual activity and alternative leisure activities, popular culture expresses this prediction as television kills your sex life. ${ }^{1}$ This paper examines the association between television ownership and coital frequency using data from nearly 4 million individuals in national household surveys in 80 countries from 5 continents.

Whether and how fast coital frequency decreases with expansion in television ownership has several major implications for understanding human behavior and for policymaking. If coital frequency is highly responsive to television ownership, this would suggest that humans are willing to substitute electronic media for intimate human companionship. Policymakers in high (low) fertility countries that are concerned with fertility rates may wish to consider subsidies, taxes, information campaigns, and other methods to promote (curtail) television ownership.

Existing economic studies in developing countries focus on the effects of television content, not television ownership, on behavior and opinions. For example, three studies provide

\footnotetext{
${ }^{1}$ For example: Herman, Jessica. 2013. “Is the Boob Tube a Buzz Kill?” Cosmopolitan.com, March 7, 2013, https://www.cosmopolitan.com/sex-love/news/a11969/TV-in-the-bedroom/ Ovenden, Olivia. 2016. “Just In: Watching TV Box Set Is Killing Your Sex Life” Esquire.com, June 6, 2016, https://www.esquire.com/uk/culture/tv/news/a10089/box-set-ruined-sex-lives/ Glamour.com. 2010. "TV in the Bedroom and Your Sex Life” Glamour.com, March 19, 2010, https://www.glamour.com/story/as-a-kid-i-always Cavallucci, Danielle. 2010. "Beware the Boob Tube in the Boudoir” HuffPost, May 17, 2010, https://www.huffingtonpost.com/danielle-cavallucci/beware-the-boob-tube-in-t_b_502716.html Brides.com. 2015. “Does Having a TV in the Bedroom Really Hurt Your Sex Life?” Brides.com, August 26, 2015, https://www.brides.com/story/having-a-tv-in-bedroom
} 
evidence that the content of television programming affects gender and health norms, including those determining fertility. Jensen and Oster (2009) found that the introduction of cable television in India improved women's status and reduced fertility. They argued that the mechanism linking cable television and women's status was the "modern” content of cable television, which changed household norms about female autonomy. La Ferrara et al. (2009) found that the expansion of soap operas in Brazil reduced fertility, and also argued that the "modern" gender norms in these soap operas was the mechanism linking soap operas to fertility. A third paper randomized whether Nigerian respondents saw a television series with an educational message about HIV/AIDS or a non-educational program. Those who saw the program with an educational message had increased likelihood of HIV testing and reduced likelihood of testing positive for a sexually transmitted infection at follow-up (Banerjee et al. 2017).

Focusing on the availability of electronics more widely, Burlando (2014) found that a large power outage in Zanzibar increased births in the short term. As this power outage eliminated access to television as well as other production and consumption technologies, including lighting, one cannot conclude that television was the mechanism linking the power outage to sexual activity.

In the United States, economic analyses of the causal effect of television ownership has used the historical expansion of television (e.g., Gentzkow 2006, Campante and Hojman 2013), which occurred during a period in which data on sexual behavior was not widely collected. Today, television ownership is nearly universal in high-income countries, making these countries an unfavorable setting for an analysis of the relationship between television ownership and coital frequency. Focusing on television content in the United States, Kearney and Levine (2015) and 
Trudeau (2016) found that a television show chronicling the experiences of pregnant and recently postpartum teenagers (i.e. MTV's 16 and Pregnant) decreased teenage fertility. ${ }^{2}$

We build on the existing studies to examine explicitly the association between television ownership and coital frequency in 80 lower income countries. ${ }^{3}$ Television ownership is a highly relevant "treatment" margin, with approximately 1 out of every 2 households in our data owning televisions. Coital frequency is both a leisure activity and reflects fertility intentions. Even as a leisure activity, more frequent intercourse increases the risk of pregnancy and sexually transmitted infections. Therefore, understanding this relationship is crucial for family planning and disease reduction or elimination.

A fundamental barrier to measuring the causal effect of television ownership on coital frequency is the endogeneity of material and sexual consumption decisions. Consumer theory predicts that income, relative prices, information, and tastes simultaneously determine television ownership and coital frequency. Another major barrier is the lack of data on sexual behavior from settings where television ownership is less than universal.

We use several strategies to address these barriers. While we cannot ensure that our estimates are causal, we take a number of steps to limit confounding factors. First, we use data from 80 countries collected as part of the Demographic and Health Surveys (DHS). This standardized national household survey collected in low- and middle-income countries contains detailed information on sexual behavior, reproductive health knowledge, consumer durables (including television) ownership, sociodemographic characteristics, and geographic location. By using comparable data across so many countries, we can include country level fixed effectscontrolling for any time invariant differences between countries about preferences or television

\footnotetext{
${ }^{2}$ Other studies outside the economics literature have looked at the portrayal of genders on TV (Durkin 1985) or the correlation between TV content and teenage sexual behavior (summary in RAND 2004).

${ }^{3}$ The survey questions are about "sexual intercourse." We cannot differentiate among sexual practices.
} 
availability. Therefore, our empirical strategy compares people within the same country. Second, these data provide substantial variation in television ownership, with approximately 50 percent of households in the data owning a television. Third, we directly control for individual level potential confounding variables such as income (or wealth) and sociodemographic and geographic characteristics associated with heterogeneity in relative prices, information, and tastes. Finally, we include information on other consumer durables ownership (e.g., refrigerator, radio, bicycle). Therefore, while not necessarily causal, the wealth of controls allows for a detailed understanding of the nature of the relationship between television ownership and coital frequency. ${ }^{4}$

Our analysis yields evidence indicating that while television may not kill your sex life, it is associated with some sex life morbidity. Put slightly differently, the results of the analysis are consistent with a small amount of substitutability between television viewing and sexual activity. We find that television ownership is associated with approximately a 6 percent (1.7 percentage point) reduction in sexual activity, a statistically significant yet not particularly large association. This finding is robust to including a variety of controls. Household wealth does not appear to be driving the main result, casting doubt on a prime omitted variables bias concern. Knowledge about reproductive health does not appear to be driving the main result either. Given our inability to rule out reverse causality—people who wish to engage in sexual intercourse less frequently might purchase a television—our results can be thought of as the maximum, in absolute value, causal relationship. And as the maximum, they are smaller than what one might expect from conventional wisdom, certainly smaller than TV killing one's sex life. We further find that having a refrigerator is associated with a decrease in the likelihood of having had sex for women, perhaps reflecting the ability to delay gratification or the relative power of women in the

\footnotetext{
${ }^{4}$ We discuss limitations of this package of strategies in further detail in the Conceptual Framework section.
} 
household. Indeed, consistent with a story of female empowerment we find that women in households with televisions are more likely to participate other household decisions. Owning a motorcycle or car is associated with an increase in the likelihood of sex in the last week, potentially reflecting that these modes of transportation facilitate anonymous sexual relations.

We provide additional evidence that the association between television ownership and coital frequency is not driven by those abstaining from sex entirely or those who would never admit to having had sex. Our point estimates are larger in absolute magnitude when we limit the estimates to those who had sex in the past 12 months.

These findings make four main contributions to the existing economic literature. First, we provide microeconometric evidence on the association between television and sexual activity, complementing existing economic literature on television and fertility (e.g., Jensen and Oster 2009, La Ferrara et al. 2012, Burlando 2014). Second, the analysis complements the economic analysis of the effects of television on other behaviors, including voting (e.g., Gentzkow 2006), educational achievement (e.g., Zavodny 2006, Gentzkow and Shapiro 2008), divorce (Chong and La Ferrara 2009), social capital (Olken 2009), political polarization (e.g., Campante and Hojman 2013), mental health (Waldman et al. 2014), fast food/soft drink consumption (Chou et al. 2008, Andreyeva et al. 2011, Grossman et al. 2012), and general consumption behavior (Bursztyn and Cantoni 2016). Third, the analysis provides suggestive evidence on a mechanism—a decline in sexual activity—possibly underlying the negative association between television viewing and happiness documented in previous economic research (Bruni and Stanca 2008). Fourth, we study access to television—a highly relevant "treatment" margin in low- and middle-income countries over the past thirty years - whereas the majority of the aforementioned studies focus on television programming content. 
The rest of the paper is organized as follows. Section 2 presents a conceptual framework. Section 3 characterizes the data and presents the statistical methods. Section 4 reports the results. Section 5 discusses the main findings and concludes.

\section{Conceptual framework}

To conceptualize the threat of television killing one's sex life, we use the lens of the standard consumer demand model. In this model, prices and income determine the choice set, which interacts with tastes to determine the optimal consumption bundle of sex and television. We may expand the model to include uncertainty, which means that beliefs (or information) also affect choice. Alternative theories, such as television having a direct epidemiological effect on libido through a biochemical pathway, are ruled out $a$ priori.

One potential concern is that both sexual activity and television ownership could be influenced by wealth and any association that we detect reflects this relationship. Higher wage income increases the opportunity costs of both television watching and sexual activity. Television ownership is a normal good (Letschert 2010), while income’s relationship with sexual frequency is unclear (Blanchflower and Oswald. 2004; Forston 2008). We will explicitly control for household wealth and other socio-demographic controls in our models to mitigate this concern.

The relationship between television and sexual activity might also occur through specific television programming: the content of television programming may convey information about the benefits and costs of sexual activity. To illuminate the empirical relevance of these mechanisms, we examine the sensitivity of the results to controlling for reproductive health knowledge. 
Ruling out the above pathways, we will focus our findings on the extent to which, as leisure activities, the two activities are potentially substitutes for each other. Owning a television reduces the price of television viewing, which may cause you to substitute television viewing for sexual activity.

Whether most sexual activity is a leisure activity or a means for procreation, or both, is an open question. Our analysis cannot disentangle these two potential motives for the activity. ${ }^{5}$ Instead, as television watching is only a substitute for the former (leisure) motive and not the latter (procreation), finding a negative association between the two likely indicates some level of substitutability. We will not be able to determine whether owning a television reflects a lower preference for sexual activity or causes it.

\section{Data and statistical methods}

\subsection{Data}

The data in this analysis are all available Demographic and Health Surveys (DHS) as of January 2018 and include surveys conducted from 1986 to $2016 .{ }^{6}$ We define the study sample to include individuals with complete responses to the main outcome of interest (i.e., timing of last sex), television ownership, and the standard socio-demographic covariates (e.g., age, years of schooling, and married). Our sample includes nearly 4 million respondents from 80 low- and middle-income countries across 5 continents. The DHS contain data on self-reported sexual frequency, asset ownership, and other demographic characteristics. Table 1 presents descriptive statistics for the study sample. Coital frequency is approximately 0.30 acts per week (Panel A). Approximately 1 out of every 2 households own a television (Panel B). Females are

\footnotetext{
${ }^{5}$ Further, the motive could differ by gender. Unfortunately, our data do not allow us to explore whether this drives some of the differences that we find when separating the sample by gender.

${ }^{6}$ See Appendix Table A1 for a list of countries and survey rounds in our study sample.
} 
overrepresented in this sample because the DHS started as a fertility survey and in many countries surveys more females than males (Panel C). ${ }^{7}$ Average age is around 30 years old.

Generally, both television ownership and sexual activity are increasing over the period. ${ }^{8}$ Across our sample, 36\% of respondents surveyed in the 1980s reported having a television. This number increases each decade with 52\% reporting owning a television in the 2010s. Reporting sexual activity in the prior week also increases over the period from $24 \%$ in the 1980 s to $35 \%$ in the 2010s. When comparing urban and rural respondents, urban respondents are about 40 percentage points more likely to report television ownership in all decades--57 percent vs. 18 percent in the 1980s and 79 percent vs. 32 percent in the 2010s. Across all decades, rural respondents are more likely than urban respondents to report sexual activity with a gap of 1 to 5 percentage points-25 percent vs. 24 percent in the 1990s and 38 percent vs. 32 percent in the 2010s. Unmarried people are slightly (2 to 5 percentage points) more likely than married people to report television ownership across all decades and much less likely (over 20 percentage points) to report having had sex in the past 7 days. Additional details on decade-specific means appear in Appendix Table A2.

\subsection{Statistical methods}

The primary conceptual difficulty in understanding the relationship between television ownership and sexual activity are confounding factors that could simultaneously affect both. Therefore, we use multivariate regression analysis to control for many, but admittedly not all, of these factors. The main regression equation is:

\footnotetext{
7 To address concerns about sample composition driving the main result, we examine the association between television ownership and sexual activity separately by female/male.

${ }^{8}$ As we control for year fixed effects in our specifications, we are not simply finding a correlation between two similarly trending variables.
} 


$$
\text { sex }_{i c t}=\gamma+\beta \text { television }_{i c t}+X_{i c t}^{\prime} \theta+\gamma_{c}+\mu_{t}+\varepsilon_{i c t}
$$

where sex $_{i c t}$ is an indicator for a particular sexual activity of individual $i$ surveyed in country $c$ in year $t$, television ict $_{\text {is }}$ an indicator variable for household television ownership, $X_{i c t}^{\prime}$ is a vector of sociodemographic controls (discussed below), $\gamma_{c}$ are country fixed effects, $\mu_{t}$ are survey year fixed effects, and $\varepsilon_{i c t}$ is an idiosyncratic error term. We use ordinary least squares (OLS) regression with heteroscedasticity-robust standard errors clustered at the country level to estimate the parameters of Equation (1).

Our specification controls for potential omitted variables in three ways. First, country fixed effects $\left(\gamma_{c}\right)$ control for any time invariant preferences or television availability differences across countries. Second, survey year fixed effects $\left(\mu_{t}\right)$ control for worldwide changes in preferences or television availability. ${ }^{9}$ Finally, we include additional individual level survey responses in the vector $X_{i c t}^{\prime}$ that control for potential seasonality (i.e. month of survey), potential changes in preferences over the lifecycle (i.e. age and marital status), socioeconomic status (i.e. education, urban residence, and wealth), and the ownership of other consumer durables to alleviate concerns outlined in Section 2. Despite these inclusions, we cannot control for all omitted variables and in our discussion we outline the limitations of the study. ${ }^{10}$

To understand whether the findings are correlations of general television watching or specific content gleaned from watching television, we also include knowledge of reproductive health.

\footnotetext{
${ }^{9}$ Our results are robust to the inclusion of country by year fixed effects.

${ }^{10}$ An alternative strategy would be to use an instrument for the ownership of a television. Unfortunately, available instruments such as tariffs or the quantity of televisions imported are either correlated with other time varying country characteristics or would fail the exclusion restriction. Further, as we focus on television ownership and not content, the introduction of a specific show would also not be a valid source of exogeneity.
} 


\section{Results}

\subsection{Main results}

Table 2 presents the main results. All specifications include country fixed effects and survey year fixed effects. Panel A displays results for the full sample. Column 1 presents the results of regressing an indicator variable for sex in the past week on an indicator variable for television ownership and indicator variables for country of residence and survey year-effectively finding the naïve association that one might guess based on people who they know. Even this point estimate is rather smaller than the "killing" one might expect. The point estimate, -0.025 , suggests that television ownership is associated with approximately a 2.5 percentage point reduction in the likelihood of having had sex in the past week (statistically significant at the $1 \%$ level). A 2.5 percentage point reduction is approximately $10 \%$ compared to the sample mean, a substantial although not particularly large association.

In Column 2, we control for total consumer durables owned, a prime omitted variables bias concern in the specification in previous column. The point estimate remains negative, statistically significant (at the 1\% level), and nearly doubles in magnitude in absolute value, suggesting that wealth is not driving the main result. In Column 3, we control for number of contraceptive methods known instead of total consumer durables owned and find a similar pattern. This would seem to indicate that neither wealth nor reproductive health knowledge are the mechanisms driving the association between television ownership and sexual activity. ${ }^{11}$

In Column 4 we include these controls for other durables ownership, reproductive health knowledge, and a full set of socio-demographic controls (i.e., age indicator variables, indicator variables for years of schooling, an indicator variable for married, and an indicator for urban

\footnotetext{
${ }^{11}$ As mentioned in the Introduction, other authors have noted the impact that television content can have on sexual health behaviors. That does not appear to be the primary mechanism here.
} 
residence). The inclusion of all of these controls reduces some omitted variables bias. As expected, the point estimate for television is somewhat attenuated, but remains statistically significant (at the $1 \%$ level). These results suggest that owning a television is associated with a lower likelihood of having had sex in the past seven days, a decline of about 6\% (1.7 percentage point decline on a mean of 30 percentage points) in our most conservative estimate (Column 4). We consider this a conservative estimate as we include as many relevant controls as possible to minimize bias. Even with these control variables, we cannot rule out reverse causation-those who prefer less frequent sexual relations could be more likely to own a television. Therefore, even this conservative estimate is likely an upper bound, in absolute value, of the underlying causal relationship. $^{12}$

In Panels B and C, we present results estimated separately for females and for males, respectively. In Columns 1 and 2 the point values are smaller for males than females and the relationship is less precisely estimated. In Column 4, the specification with the most number of controls, the estimated association is a relatively precisely measured 0 for males. Therefore, the relationship in the first three columns for males was the result of the correlation between television ownership and other individual level observables. Once these observables are included, the relationship disappears. Also, note the sample size for males is only 20 percent of the size for females, also potentially affecting statistical precision. The results suggest that females are driving the association in Panel A. We discuss the potential reasons for this in the Mechanisms section.

\subsection{Do other consumer durables kill your sex life?}

\footnotetext{
${ }^{12}$ In results not presented, we further include survey year fixed effects times country fixed effects as additional regressors. This marginally reduces the point estimate to -0.012 with statistical significance at the 1 percent level.
} 
Given the findings thus far one could ask, "do other consumer durables kill your sex life?” Table 3 explores this research question by examining the associations between several of the other main consumer durables asked about in the DHS and sexual activity using the same specification as Column 4 in Table $2 .{ }^{13}$ Consistent with modes of transportation making sexual activity easier, the ownership of a motorcycle or car are associated with increases in sexual activity. Individuals with these modes of transportation can more readily seek out anonymous sex or travel away from prying eyes to engage in sex. Cars can also be used as a setting for a sexual encounter (Lewis 1980). Further, this ownership might reflect having to travel greater distance for work, making maintaining multiple relationships more likely. Finally, this could instead reflect road proximity, echoing the findings of Djemai (2018) that those living closer to a paved road are more likely to be HIV positive in part because they can more readily engage in risky sexual encounters.

Perhaps more surprisingly we find a negative association between refrigerator ownership and having had sex in the past week for women. As with our main result of TV and coital frequency, we cannot assign a causal interpretation to this coefficient. Instead, this could reflect a joint utility determination-people who seek the ability to routinely forgo food consumption today for food consumption tomorrow, i.e. refrigerate uneaten food, might also be more likely to forgo other consumption activities, i.e. sexual relations. Alternatively, female empowerment could be driving this relationship-women with more bargaining power in the household could be more likely to own refrigerators and refuse sexual relations. We explicitly test the association between television ownership and women's role in household decision making below.

\subsection{Does television kill your risqué lifestyle?}

\footnotetext{
${ }^{13}$ Recall that Table 2 Columns 2 and 4 included consumer durables as controls. Therefore, the effects presented in that table were net of any effects presented here.
} 
Television may substitute for characteristics of your sex life other than coital frequency or may influence which characteristics are preferred. In that sense, television may kill your risqué lifestyle if not your entire sex life. Table 4 examines this question by regressing three additional measures of sexual behavior on television ownership: an indicator variable for multiple partners in the past 12 months, an indicator variable (for males) for paying money for sex in the past 12 months, and an indicator variable for not using a condom at last sex in the past 12 months. Overall, the coefficient estimates suggest little overall association between television ownership and risqué behavior with small and statistically insignificant point estimates. The one exception is that for males the association for lack of condom use is negative and statistically significant—men with televisions are more likely to have used a condom during their last sexual encounter. One explanation for the overall lack of statistical significance in this set of regressions is that the overall reported prevalence of multiple partnerships in the full sample and transactional sex is low (i.e. approximately 1 to $2 \%$ ).

\subsection{Additional heterogeneity}

In Table 5 we test for additional heterogeneity by age, marital status, years of schooling, and whether the respondent lives in an urban location. In each case, we keep the dummy variable for television ownership and additionally include an interaction between this dummy and the characteristic of interest as an additional covariate in equation 1. Each column includes the results for a separate interaction term. Each Panel is a separate sample—full, females, and males. We find positive and insignificant relationships by age, being married, number of years of schooling, and living in an urban location for both the full sample and women only (Panels A and B). For men, the interaction for years of schools and living in an urban area appear to dampen the relationship between television ownership and sexual activity as can be seen with 
positive and statistically insignificant coefficients on the interaction terms in Panel C, Columns 3 and 4. For example, for males with zero years of schooling, television ownership is associated with a 2.4 percentage point reduction in the likelihood of sex in the past week. For males with 8 years of schooling, the estimated association is zero and for males with more than 8 years of schooling, the estimated association becomes positive. The average years of schooling of men in our sample is 6.7. In Column 2, across all samples we find that the overall relationship (sum of the coefficient on television and television times married) for married individuals is statistically insignificant, while the main effect remains statistically significant for the full sample and women only.

\subsection{Mechanisms and robustness checks}

We are unable to test directly the reasons behind the association between television and coital frequency. In Table 6 we test additional outcomes that could be mechanisms. Panel A contains the results for the full sample, while Panel B is women only, and Panel C is men only. In Column 1, we test the association between television ownership and the ideal number of children. Across all three panels, owning a television is associated with a negative and significant decrease in the reported ideal family size: 0.18 for women and 0.34 for men. Relative to the sample means, these are 5 percent reduction for women and 7 percent reduction for men. Therefore, television content might be decreasing ideal family size or households who desire smaller families could be purchasing televisions to use television watching as a substitute for sexual relations.

In Columns 2 and 3 we test the relationship between television ownership and female empowerment. Female empowerment is both consistent with the prior literature on television show content increasing women's bargaining power and the negative relationship between sex 
and owning a refrigerator — the content of these shows might empower women to refuse sex and these empowered women might also negotiate refrigeration ownership. Starting in 1992, some DHS surveys asked female respondents whether they had sole or joint decision-making power over contraceptive use. In Column 2, we control for a dummy variable indicating an affirmative response and find no statistically significant relationship. Starting in 1997 some DHS asked women whether they participate in four separate household decisions-“woman's own health care,” “major household purchases,” "purchases for daily household needs,” and “visits to her family or relatives.” In Column 3, we use the number of these decisions in which a respondent takes part as a dependent variable. Television ownership is associated with women taking part in 0.07 more decisions, an increase of 3 percent over the mean of 2.03. As these are only associations, we cannot know whether empowered women are more likely to own televisions or television ownership influences the household decision making process. ${ }^{14}$

Table 7 displays the results of a variety of robustness checks concerning timing. Column 1 repeats the estimates from our preferred specification (Table 2, Column 4) for ease of comparison. In Columns 2-6, we examine sexual activity at 2 days, 14 days, 31 days, 3 months, and 12 months, respectively. The point estimates are roughly similar for each of these outcomes (0.011 to 0.017 ) but on an increasing mean. Therefore, while in percentage point terms it is roughly constant, in percentage terms, the largest percentage change is 7 percent at the two day measure and the smallest is 2 percent at the 3 and 12 month measures.

Table 8 contains a number of other robustness checks that limit the sample in different ways. In Column 1, we again repeat the estimates from our preferred specification (Table 2, Column 4) for ease of comparison. In Column 2, we return to examining sexual activity within

\footnotetext{
14 The sample over which these questions were asked is smaller than our primary sample. The results in Table 2 are robust to estimating them over this limited sample.
} 
the past week, but limit the regression sample to those who have had sex in the past year. In Column 3, we limit the regression sample to the more recent DHS survey rounds (i.e. 20062016). In both of these robustness checks, the point estimate on television is almost identical to the original estimates in both magnitude and statistical significance. Column 4 limits the sample to those age 25 and older and Column 5 limits the sample to currently married. The coefficients of interest in the final two columns are almost identical to each other and larger in absolute magnitude than the original estimates.

\section{Discussion and conclusion}

Does television kill your sex life? Popular culture claims "Yes." A former health and family welfare minister of India claimed it could dramatically decrease population growth. Evidence from nearly 4 million individuals in 80 countries from 5 continents suggests “a little.” We find that television ownership is associated with approximately a 6\% reduction in sexual activity, a statistically significant yet not particularly large association. These results are robust to controlling for household wealth, suggesting that a prime omitted variables bias hypothesiswealthier households are simultaneously more likely to own a television and have lower levels of sexual activity—seemingly is not a concern. Further, if admitting to sex is more taboo for higher status individuals, as long as owning other consumer durables and educational attainment are decent proxies for an individual's status, then we have eliminated this channel as well. In addition, the results suggest that knowledge about reproductive health is not driving the association between television ownership and sexual activity. Despite controlling for many of the potentially confounding factors, ultimately this finding is at most suggestively causal as we 
cannot rule out that people who prefer less frequent intercourse are more likely to own a television.

Regardless of the causal channel, reduced sexual frequency should result in fewer births. Assuming that the 6 percent decrease that we measure is similar across both sex for procreation and non-procreation purposes, we might expect then a 6 percent decline in overall births. This percent decline is similar in magnitude to the 5 percent reduction we estimate for ideal family size among women with televisions.

More recently, popular culture has claimed that smartphones are killing people's sex lives. Our study population resides in low- and middle-income countries and were surveyed largely around 2010, before the widespread availability of smartphones. In countries with ubiquitous smartphones, the smartphone might be the real sex life killer. Future research might examine this question. 


\section{References}

Andreyeva, Tatiana, Inas Rashad Kelly, and Jennifer L. Harris. 2011. Exposure to food advertising on television: Associations with children's fast food and soft drink consumption and obesity. Economics \& Human Biology, 9(3): 221-233.

Banerjee, Abhijit, Eliana La Ferrara and Victor Orozco. 2017. The entertaining way to behavioral change. MIT working paper.

Blakely, Rhys. 2009. “Ghulam Nabi Azad says late night TV will help slow India’s birth rate.” July 13, 2009. The Times, United Kingdom.

Blanchflower, David and Andrew J. Oswald 2004. "Money, Sex, and Happiness: An Empirical Study.” Scandinavian Journal of Economics, 106(3), 393-415.

Brides.com. 2015. “Does Having a TV in the Bedroom Really Hurt Your Sex Life?” Brides.com, August 26, 2015, https://www.brides.com/story/having-a-tv-in-bedroom

Bruni, Luigino, and Luca Stanca. Watching alone: Relational goods, television and happiness. Journal of Economic Behavior \& Organization, 65(3): 506-528.

Burlando, Alfredo. 2014. Power outages, power externalities, and baby booms. Demography, 51(4): 1477-1500.

Bursztyn, Leonardo, and Davide Cantoni. 2016. A tear in the iron curtain: The impact of Western television on consumption behavior. Review of Economics and Statistics, 98(1): 25-41.

Campante, Filipe R., and Daniel A. Hojman. 2013. Media and polarization: Evidence from the introduction of broadcast TV in the United States. Journal of Public Economics, 100 (2013): 7992.

Cavallucci, Danielle. 2010. "Beware the Boob Tube in the Boudoir" HuffPost, May 17, 2010, https://www.huffingtonpost.com/danielle-cavallucci/beware-the-boob-tube-in-t_b_502716.html

Chong, Alberto, and Eliana La Ferrara. 2009. Television and divorce: Evidence from Brazilian novelas. Journal of the European Economic Association, 7(2-3): 458-468.

Chou, Shin-Yi, Inas Rashad, and Michael Grossman. 2008. Fast-food restaurant advertising on television and its influence on childhood obesity. The Journal of Law and Economics, 51(4): 599-618.

Djemai, Elodie. 2018. Roads and the spread of HIV in Africa. Journal of Health Economics, 60: 118-141.

Gentzkow, Matthew. 2006. Television and voter turnout. The Quarterly Journal of Economics, 121(3): 931-972. 
Gentzkow, Matthew, and Jesse M. Shapiro. 2008. Preschool television viewing and adolescent test scores: Historical evidence from the Coleman study. The Quarterly Journal of Economics, 123(1): 279-323.

Glamour.com. 2010. "TV in the Bedroom and Your Sex Life” Glamour.com, March 19, 2010, https://www.glamour.com/story/as-a-kid-i-always

Grossman, Michael, Erdal Tekin, and Roy Wada. 2012. Fast-food restaurant advertising on television and its influence on youth body composition. NBER Working Paper No. 18640.

Herman, Jessica. 2013. "Is the Boob Tube a Buzz Kill?” Cosmopolitan.com, March 7, 2013, https://www.cosmopolitan.com/sex-love/news/a11969/TV-in-the-bedroom/

Jensen, Robert, and Emily Oster. 2009. The power of TV: Cable television and women's status in India. The Quarterly Journal of Economics, 124(3): 1057-1094.

Kearney, M. and P. Levine. (2015). Media Influences on Social Outcomes: The Impact of MTV's 16 and Pregnant on Teen Childbearing. The American Economic Review, 105(12), 3597-3632

La Ferrara, Eliana, Alberto Chong, and Suzanne Duryea. 2012. Soap operas and fertility: Evidence from Brazil. American Economic Journal: Applied Economics, 4(4): 1-31.

Letschert, Virginie and Michael McNeal 2010. "Material World: Forecasting Household Appliance Owernship in a Growing Global Economy.” Lawrence Berkeley National Laboratory.

Lewis, David 1980. Sex and the Automobile: From Ruble Seats to Rockin’ Vans. Michigan Quarterly Review. 518-528.

Olken, Benjamin. 2009. Do television and radio destroy social capital. Evidence from Indonesian Villages. American Economic Journal: Applied Economics, 1(4): 1-33.

Ovenden, Olivia. 2016. “Just In: Watching TV Box Set Is Killing Your Sex Life” Esquire.com, June 6, 2016, https://www.esquire.com/uk/culture/tv/news/a10089/box-set-ruined-sex-lives/

Trudeau, J. (2016). The role of new media on teen sexual behaviors and fertility outcomes - the case of 16 and Pregnant. Southern Economic Journal, 82(3), 975-1003.

Waldman, Michael, Sean Nicholson, and Nodir Adilov. 2014. Positive and negative mental health consequences of early childhood television watching. NBER working paper 17786.

Zavodny, Madeline. 2006. Does watching television rot your mind? Estimates of the effect on test scores. Economics of Education Review, 25(5): 565-573. 
Table 1: Descriptive Statistics

\begin{tabular}{|c|c|c|c|}
\hline Sample: & $\frac{\text { Full Sample }}{(1)}$ & $\frac{\text { Females }}{(2)}$ & $\frac{\text { Males }}{(3)}$ \\
\hline \multicolumn{4}{|l|}{ Panel A: Sex life } \\
\hline Sex in past week & $\begin{array}{c}0.30 \\
(0.46)\end{array}$ & $\begin{array}{c}0.30 \\
(0.46)\end{array}$ & $\begin{array}{c}0.33 \\
(0.47)\end{array}$ \\
\hline Sex in past 2 days & $\begin{array}{c}0.16 \\
(0.37)\end{array}$ & $\begin{array}{c}0.16 \\
(0.37)\end{array}$ & $\begin{array}{c}0.18 \\
(0.39)\end{array}$ \\
\hline Sex in past 14 days & $\begin{array}{c}0.40 \\
(0.49)\end{array}$ & $\begin{array}{c}0.39 \\
(0.49)\end{array}$ & $\begin{array}{c}0.43 \\
(0.50)\end{array}$ \\
\hline Sex in past 31 days & $\begin{array}{c}0.47 \\
(0.50)\end{array}$ & $\begin{array}{c}0.46 \\
(0.50)\end{array}$ & $\begin{array}{c}0.51 \\
(0.50)\end{array}$ \\
\hline Sex in past 3 months & $\begin{array}{c}0.56 \\
(0.50)\end{array}$ & $\begin{array}{c}0.55 \\
(0.50)\end{array}$ & $\begin{array}{c}0.63 \\
(0.48)\end{array}$ \\
\hline Sex in past year & $\begin{array}{c}0.64 \\
(0.48)\end{array}$ & $\begin{array}{c}0.63 \\
(0.48)\end{array}$ & $\begin{array}{c}0.70 \\
(0.46)\end{array}$ \\
\hline Multiple partners & $\begin{array}{c}0.02 \\
(0.15)\end{array}$ & $\begin{array}{c}0.01 \\
(0.09)\end{array}$ & $\begin{array}{c}0.10 \\
(0.30)\end{array}$ \\
\hline Money for sex & $\begin{array}{l}- \\
-\end{array}$ & $\begin{array}{l}- \\
-\end{array}$ & $\begin{array}{c}0.02 \\
(0.13)\end{array}$ \\
\hline No condom at last sex & $\begin{array}{c}0.48 \\
(0.50)\end{array}$ & $\begin{array}{c}0.47 \\
(0.50)\end{array}$ & $\begin{array}{c}0.54 \\
(0.50)\end{array}$ \\
\hline $\begin{array}{l}\text { Panel B: Consumer dur } \\
\text { Television }\end{array}$ & $\begin{array}{c}0.48 \\
(0.50)\end{array}$ & $\begin{array}{c}0.49 \\
(0.50)\end{array}$ & $\begin{array}{c}0.41 \\
(0.49)\end{array}$ \\
\hline Refrigerator & $\begin{array}{c}0.28 \\
(0.45)\end{array}$ & $\begin{array}{c}0.29 \\
(0.45)\end{array}$ & $\begin{array}{c}0.22 \\
(0.42)\end{array}$ \\
\hline Radio & $\begin{array}{c}0.61 \\
(0.49)\end{array}$ & $\begin{array}{c}0.61 \\
(0.49)\end{array}$ & $\begin{array}{c}0.60 \\
(0.49)\end{array}$ \\
\hline Improved floor & $\begin{array}{c}0.47 \\
(0.50)\end{array}$ & $\begin{array}{c}0.47 \\
(0.50)\end{array}$ & $\begin{array}{c}0.49 \\
(0.50)\end{array}$ \\
\hline Car & $\begin{array}{c}0.09 \\
(0.28)\end{array}$ & $\begin{array}{c}0.09 \\
(0.29)\end{array}$ & $\begin{array}{c}0.08 \\
(0.27)\end{array}$ \\
\hline Motorcycle & $\begin{array}{c}0.15 \\
(0.36)\end{array}$ & $\begin{array}{c}0.15 \\
(0.36)\end{array}$ & $\begin{array}{c}0.17 \\
(0.37)\end{array}$ \\
\hline Bicycle & $\begin{array}{c}0.30 \\
(0.46)\end{array}$ & $\begin{array}{c}0.30 \\
(0.46)\end{array}$ & $\begin{array}{c}0.33 \\
(0.47)\end{array}$ \\
\hline Total consumer durables & $\begin{array}{c}1.91 \\
(1.44)\end{array}$ & $\begin{array}{c}1.93 \\
(1.43)\end{array}$ & $\begin{array}{c}2.30 \\
(1.71)\end{array}$ \\
\hline \multicolumn{4}{|l|}{ Panel C: Other covariates } \\
\hline Female & $\begin{array}{c}0.83 \\
(0.37)\end{array}$ & $\begin{array}{l}1.00 \\
0.00\end{array}$ & $\begin{array}{c}0.00 \\
0.00\end{array}$ \\
\hline Age & $\begin{array}{l}29.96 \\
(9.97)\end{array}$ & $\begin{array}{l}29.67 \\
(9.58)\end{array}$ & $\begin{array}{c}31.42 \\
(11.60)\end{array}$ \\
\hline Married & $\begin{array}{c}0.69 \\
(0.46)\end{array}$ & $\begin{array}{c}0.70 \\
(0.46)\end{array}$ & $\begin{array}{c}0.60 \\
(0.49)\end{array}$ \\
\hline Years of schooling & $\begin{array}{c}5.93 \\
(4.84)\end{array}$ & $\begin{array}{c}5.77 \\
(4.86)\end{array}$ & $\begin{array}{c}6.70 \\
(4.69)\end{array}$ \\
\hline Urban & $\begin{array}{c}0.43 \\
(0.50)\end{array}$ & $\begin{array}{c}0.44 \\
(0.50)\end{array}$ & $\begin{array}{c}0.41 \\
(0.49)\end{array}$ \\
\hline Observations & $3,817,006$ & $3,176,850$ & 640,156 \\
\hline
\end{tabular}


Table 2: Does Television Kill Your Sex Life?

Dependent variable:

Panel A: Full Sample

Television

Observations

Sample mean of dependent variable

Panel B: Females

Television

Observations

Sample mean of dependent variable

\section{Panel C: Males}

Television

Observations

Sample mean of dependent variable

Country fixed effects?

Survey year fixed effects?

Control for total consumer durables?

Control for reproductive health knowledge?

Additional socio-demographic controls?
$-0.025 * * *$

(0.007)

$\begin{array}{cccc}-0.025^{* * *} & -0.040^{* * *} & -0.051^{* * *} & -0.017^{* * *} \\ (0.007) & (0.007) & (0.008) & (0.005) \\ 3,817,006 & 3,817,006 & 3,817,006 & 3,817,006 \\ 0.30 & 0.30 & 0.30 & 0.30\end{array}$

Sex in the past week (yes $=1$, no=0)

(2)

(3)

(4)

(1)

0.30

$-0.043^{* * *}$

(0.008)

$-0.048 * * *$

(0.008)

$-0.017 * * *$

(0.005)

3,176,850

3,176,850

$3,176,850$

$3,176,850$

0.30

0.30

0.30

0.30

Notes: Data come from Standard Demographic and Health Surveys (DHS). "Sex in the past week" is an indicator variable. "Television" is an indicator variable. "Additional socio-demographic controls" include the full set of indicator variables for age, married, years of schooling, urban residence, and interview month. Parameters estimated using ordinary least squares (OLS) regression. Robust standard errors in parentheses are clustered at country level.

*** Significant at the 1 percent level, ** Significant at the 5 percent level, * Significant at the 10 percent level. 
Table 3: Do Other Consumer Durables Kill Your Sex Life?

\begin{tabular}{|c|c|c|c|}
\hline \multirow{3}{*}{$\begin{array}{l}\text { Dependent variable: } \\
\text { Sample: }\end{array}$} & \multicolumn{3}{|c|}{ Sex in the past week (yes $=1, \mathrm{no}=0$ ) } \\
\hline & Full sample & Females & Males \\
\hline & $(1)$ & $(2)$ & $(3)$ \\
\hline \multicolumn{4}{|l|}{ Regressor: } \\
\hline Refrigerator & $\begin{array}{l}-0.010 \\
(0.005)\end{array}$ & $\begin{array}{c}-0.012^{* *} \\
(0.005)\end{array}$ & $\begin{array}{c}0.009 \\
(0.006)\end{array}$ \\
\hline Radio & $\begin{array}{l}-0.004 \\
(0.007)\end{array}$ & $\begin{array}{l}-0.006 \\
(0.006)\end{array}$ & $\begin{array}{l}-0.006 \\
(0.004)\end{array}$ \\
\hline Bicycle & $\begin{array}{c}0.001 \\
(0.004)\end{array}$ & $\begin{array}{c}0.001 \\
(0.004)\end{array}$ & $\begin{array}{c}0.003 \\
(0.003)\end{array}$ \\
\hline Motorcycle & $\begin{array}{c}0.011^{* *} \\
(0.005)\end{array}$ & $\begin{array}{c}0.013^{* * *} \\
(0.004)\end{array}$ & $\begin{array}{c}0.017^{* *} \\
(0.005)\end{array}$ \\
\hline Car & $\begin{array}{c}0.018^{* * *} \\
(0.006)\end{array}$ & $\begin{array}{c}0.018^{* * *} \\
(0.006)\end{array}$ & $\begin{array}{c}0.014^{* *} \\
(0.004)\end{array}$ \\
\hline Improved floor & $\begin{array}{l}-0.008 \\
(0.008)\end{array}$ & $\begin{array}{l}-0.012 \\
(0.009)\end{array}$ & $\begin{array}{c}-0.020 * * * \\
(0.003)\end{array}$ \\
\hline Country fixed effects? & YES & YES & YES \\
\hline Survey year fixed effects? & YES & YES & YES \\
\hline Control for total consumer durables? & YES & YES & YES \\
\hline Control for reproductive health knowledge? & YES & YES & YES \\
\hline Additional socio-demographic controls? & YES & YES & YES \\
\hline Observations & $3,817,006$ & $3,176,850$ & 640,156 \\
\hline Sample mean of dependent variable & 0.30 & 0.30 & 0.33 \\
\hline
\end{tabular}

Notes: Data come from Standard Demographic and Health Surveys (DHS). Each coefficient estimate comes from a separate regression. Improved floor is an indicator variable equal to one if the respondent's household's floor is wood, brick, concrete, tile, or other improved material. "Additional socio-demographic controls" include the full set of indicator variables for age, married, years of schooling, urban residence, and interview month. Parameters estimated using ordinary least squares (OLS) regression. Robust standard errors in parentheses are clustered at country level.

*** Significant at the 1 percent level, ** Significant at the 5 percent level, * Significant at the 10 percent level. 
Table 4: Does Television Kill Your Risque Behavior?

\section{Dependent variable: \\ Panel A: Full sample}

Television

Observations

Sample mean of dependent variable

\section{Panel B: Females}

Television

Observations

Sample mean of dependent variable

\section{Panel C: Males}

Television

Observations

Sample mean of dependent variable
Multiple partners

(1)

$$
\begin{gathered}
-0.002 \\
(0.001) \\
3,817,006 \\
0.02
\end{gathered}
$$

$-0.001$

$3,176,850$

0.01

$-$$$
-
$$$$
0.001
$$

$-$

3,817,006

0.48

No condom

(3)

(2)

$-0.004$

(0.009)

$3,176,850$

0.47

$\begin{array}{lll}-0.002 & 0.000 & -0.008 * * *\end{array}$

$(0.001)$

(0.004)

640,156

640,156

640,156

0.10

0.02

0.54

Country fixed effects?

$\begin{array}{ccc}\text { YES } & \text { YES } & \text { YES } \\ \text { YES } & \text { YES } & \text { YES } \\ \text { YES } & \text { YES } & \text { YES } \\ \text { YES } & \text { YES } & \text { YES } \\ \text { YES } & \text { YES } & \text { YES }\end{array}$

Notes: Data come from Standard Demographic and Health Surveys (DHS). "Sex in the past week" is an indicator variable. "Television" is an indicator variable. "Additional socio-demographic controls" include the full set of indicator variables for age, married, years of schooling, urban residence, and interview month. Parameters estimated using ordinary least squares (OLS) regression. Robust standard errors in parentheses are clustered at country level.

*** Significant at the 1 percent level, ** Significant at the 5 percent level, * Significant at the 10 percent level. 
Table 5: Additional Heterogeneity Analyses

\begin{tabular}{|c|c|c|c|c|}
\hline \multirow[t]{2}{*}{ Dependent variable: } & \multicolumn{4}{|c|}{ Sex in the past week (yes $=1, \mathrm{no}=0$ ) } \\
\hline & $(1)$ & $(2)$ & (3) & $(4)$ \\
\hline \multicolumn{5}{|l|}{ Panel A: Full Sample } \\
\hline Television & $\begin{array}{l}-0.021 * \\
(0.012)\end{array}$ & $\begin{array}{c}-0.028 * * \\
(0.012)\end{array}$ & $\begin{array}{c}-0.023^{* * *} \\
(0.008)\end{array}$ & $\begin{array}{c}-0.020^{* * *} \\
(0.006)\end{array}$ \\
\hline Television * Age & $\begin{array}{c}0.0001 \\
(0.0004)\end{array}$ & & & \\
\hline Television * Married & & $\begin{array}{c}0.016 \\
(0.016)\end{array}$ & & \\
\hline Television * Years of schooling & & & $\begin{array}{c}0.001 \\
(0.001)\end{array}$ & \\
\hline Television * Urban & & & & $\begin{array}{c}0.006 \\
(0.004)\end{array}$ \\
\hline $\mathrm{P}>\mathrm{F}\left(\mathrm{TV}+\mathrm{TV}^{*}\right.$ Covariate $\left.=0\right)$ & 0.070 & 0.132 & 0.003 & 0.006 \\
\hline Observations & $3,817,006$ & $3,817,006$ & $3,817,006$ & $3,817,006$ \\
\hline Sample mean of dependent variable & 0.30 & 0.30 & 0.30 & 0.30 \\
\hline \multicolumn{5}{|l|}{ Panel B: Females } \\
\hline Television & $\begin{array}{c}-0.035^{* * *} \\
(0.014)\end{array}$ & $\begin{array}{c}-0.036 * * \\
(0.014)\end{array}$ & $\begin{array}{c}-0.022 * * * \\
(0.008)\end{array}$ & $\begin{array}{c}-0.018 * * * \\
(0.006)\end{array}$ \\
\hline Television * Age & $\begin{array}{c}0.001 \\
(0.0004)\end{array}$ & & & \\
\hline Television * Married & & $\begin{array}{c}0.026 \\
(0.018)\end{array}$ & & \\
\hline Television * Years of schooling & & & $\begin{array}{c}0.001 \\
(0.001)\end{array}$ & \\
\hline Television * Urban & & & & $\begin{array}{c}0.002 \\
(0.004)\end{array}$ \\
\hline $\mathrm{P}>\mathrm{F}(\mathrm{TV}+\mathrm{TV} *$ Covariate $=0)$ & 0.012 & 0.185 & 0.006 & 0.001 \\
\hline Observations & $3,176,850$ & $3,176,850$ & $3,176,850$ & $3,176,850$ \\
\hline Sample mean of dependent variable & 0.30 & 0.30 & 0.30 & 0.30 \\
\hline \multicolumn{5}{|l|}{ Panel C: Males } \\
\hline Television & $\begin{array}{c}-0.011 \\
(0.012)\end{array}$ & $\begin{array}{l}-0.008 \\
(0.007)\end{array}$ & $\begin{array}{c}-0.024 * * \\
(0.010)\end{array}$ & $\begin{array}{c}-0.009 \\
(0.007)\end{array}$ \\
\hline Television * Age & $\begin{array}{l}0.0003 \\
(0.004)\end{array}$ & & & \\
\hline Television * Married & & $\begin{array}{c}0.013 \\
(0.013)\end{array}$ & & \\
\hline Television * Years of schooling & & & $\begin{array}{c}0.003^{* * *} \\
(0.001)\end{array}$ & \\
\hline Television * Urban & & & & $\begin{array}{c}0.018 * * \\
(0.007)\end{array}$ \\
\hline $\mathrm{P}>\mathrm{F}\left(\mathrm{TV}+\mathrm{TV}^{*}\right.$ Covariate $\left.=0\right)$ & 0.374 & 0.580 & 0.029 & 0.065 \\
\hline Observations & 640,156 & 640,156 & 640,156 & 640,156 \\
\hline Sample mean of dependent variable & 0.33 & 0.33 & 0.33 & 0.33 \\
\hline Country fixed effects? & YES & YES & YES & YES \\
\hline Survey year fixed effects? & YES & YES & YES & YES \\
\hline Control for total consumer durables? & YES & YES & YES & YES \\
\hline Control for reproductive health knowledge? & YES & YES & YES & YES \\
\hline Additional socio-demographic controls? & YES & YES & YES & YES \\
\hline
\end{tabular}




\begin{tabular}{|c|c|c|c|}
\hline Dependent variable: & $\begin{array}{c}\text { Ideal number of } \\
\text { children }\end{array}$ & $\begin{array}{c}\text { Decide } \\
\text { contraception }\end{array}$ & $\begin{array}{r}\text { Number of } \\
\text { househ } \\
\text { decisio } \\
\end{array}$ \\
\hline & $(1)$ & $(2)$ & $(3)$ \\
\hline \multicolumn{4}{|l|}{ Panel A: Full Sample } \\
\hline Television & $\begin{array}{c}-0.205^{* * *} \\
(0.048)\end{array}$ & $\begin{array}{l}- \\
-\end{array}$ & $\begin{array}{l}- \\
-\end{array}$ \\
\hline Observations & $3,531,848$ & - & - \\
\hline Sample mean of dependent variable & 3.89 & - & - \\
\hline \multicolumn{4}{|l|}{ Panel B: Females } \\
\hline Television & $\begin{array}{c}-0.178^{* * *} \\
(0.037)\end{array}$ & $\begin{array}{c}0.003 \\
(0.007)\end{array}$ & $\begin{array}{r}0.070^{*} \\
(0.024\end{array}$ \\
\hline Observations & $2,936,413$ & 596,302 & $1,312,5$ \\
\hline Sample mean of dependent variable & 3.73 & 0.27 & 2.03 \\
\hline \multicolumn{4}{|l|}{ Panel C: Males } \\
\hline Television & $\begin{array}{c}-0.339 * * * \\
(0.110)\end{array}$ & - & $\begin{array}{l}- \\
-\end{array}$ \\
\hline Observations & 595,435 & - & - \\
\hline Sample mean of dependent variable & 4.66 & - & - \\
\hline Country fixed effects? & YES & YES & YES \\
\hline Survey year fixed effects? & YES & YES & YES \\
\hline Control for total consumer durables? & YES & YES & YES \\
\hline Control for reproductive health knowledge? & YES & YES & YES \\
\hline Additional socio-demographic controls? & YES & YES & YES \\
\hline
\end{tabular}

Notes: Data come from female respondents in Standard Demographic and Health Surveys (DHS). "Sex in the past week" is an indicator variable. "Television" is an indicator variable. "Ideal number of children" is a count variable for desired number of children. "Decide contraception" is an indicator variable for the female respondent having sole/joint decision-making power for contraception, available in some sample countries beginning in 1992. "Number of main household decisions" is the total number of the four main household decisions the DHS uses as a measure of female participation in household decision-making, avaible in some sample countries beginning in 1997: "woman's own health care", "major household purchases, "purchases for daily household needs", and "visits to her family or relatives". "Additional socio-demographic controls" include the full set of indicator variables for age, married, years of schooling, urban residence, and interview month. Parameters estimated using ordinary least squares (OLS) regression. Robust standard errors in parentheses are clustered at country level.

*** Significant at the 1 percent level, ** Significant at the 5 percent level, * Significant at the 10 percent level. 
Table 7: Robustness Checks--Timing

\begin{tabular}{|c|c|c|c|c|c|c|}
\hline \multirow[t]{2}{*}{ Dependent variable: } & $\begin{array}{c}\text { Sex in past } \\
7 \text { days } \\
\end{array}$ & $\begin{array}{c}\text { Sex in past } \\
2 \text { days } \\
\end{array}$ & $\begin{array}{c}\text { Sex in past } \\
14 \text { days } \\
\end{array}$ & $\begin{array}{c}\text { Sex in past } \\
31 \text { days } \\
\end{array}$ & $\begin{array}{c}\text { Sex in past } \\
3 \text { months }\end{array}$ & $\begin{array}{l}\text { Sex in past } \\
12 \text { months } \\
\end{array}$ \\
\hline & $(1)$ & $(2)$ & $(3)$ & $(4)$ & $(5)$ & $(6)$ \\
\hline \multicolumn{7}{|l|}{ Panel A: Full sample } \\
\hline Television & $\begin{array}{c}-0.017 * * * \\
(0.005)\end{array}$ & $\begin{array}{c}-0.011 * * * \\
(0.004)\end{array}$ & $\begin{array}{c}-0.016 * * * \\
(0.006)\end{array}$ & $\begin{array}{c}-0.015 * * \\
(0.006)\end{array}$ & $\begin{array}{c}-0.012 * * \\
(0.006)\end{array}$ & $\begin{array}{c}-0.014 * * \\
(0.006)\end{array}$ \\
\hline Observations & $3,817,006$ & $3,817,006$ & $3,817,006$ & $3,817,006$ & $3,817,006$ & $3,817,006$ \\
\hline Sample mean of dependent variable & 0.30 & 0.16 & 0.40 & 0.47 & 0.56 & 0.64 \\
\hline \multicolumn{7}{|l|}{ Panel B: Females } \\
\hline Television & $\begin{array}{c}-0.017 * * * \\
(0.005)\end{array}$ & $\begin{array}{c}-0.011 * * * \\
(0.003)\end{array}$ & $\begin{array}{c}-0.015 * * * \\
(0.005)\end{array}$ & $\begin{array}{c}-0.013 * * * \\
(0.005)\end{array}$ & $\begin{array}{l}-0.009 * \\
(0.005)\end{array}$ & $\begin{array}{c}-0.011^{* *} \\
(0.005)\end{array}$ \\
\hline Observations & $3,176,850$ & $3,176,850$ & $3,176,850$ & $3,176,850$ & $3,176,850$ & $3,176,850$ \\
\hline Sample mean of dependent variable & 0.30 & 0.16 & 0.39 & 0.46 & 0.55 & 0.63 \\
\hline \multicolumn{7}{|l|}{ Panel C: Males } \\
\hline Television & $\begin{array}{c}0.000 \\
(0.005)\end{array}$ & $\begin{array}{c}0.000 \\
(0.005)\end{array}$ & $\begin{array}{c}0.004 \\
(0.005)\end{array}$ & $\begin{array}{c}0.006 \\
(0.004)\end{array}$ & $\begin{array}{c}0.004 \\
(0.004)\end{array}$ & $\begin{array}{c}0.002 \\
(0.004)\end{array}$ \\
\hline Observations & 640,156 & 640,156 & 640,156 & 640,156 & 640,156 & 640,156 \\
\hline Sample mean of dependent variable & 0.33 & 0.18 & 0.43 & 0.51 & 0.63 & 0.70 \\
\hline Country fixed effects? & YES & YES & YES & YES & YES & YES \\
\hline Survey year fixed effects? & YES & YES & YES & YES & YES & YES \\
\hline Control for total consumer durables? & YES & YES & YES & YES & YES & YES \\
\hline Control for reproductive health knowledge? & YES & YES & YES & YES & YES & YES \\
\hline Additional socio-demographic controls? & YES & YES & YES & YES & YES & YES \\
\hline
\end{tabular}

Notes: Data come from Standard Demographic and Health Surveys (DHS). "Sex in past X days" is an indicator variable. "Television" is an indicator variable. "Additional socio-demographic controls" include the full set of indicator variables for age, married, years of schooling, urban residence, and interview month. Parameters estimated using ordinary least squares (OLS) regression. Robust standard errors in parentheses are clustered at country level. Column 1: repeats Table 2 column 4.

*** Significant at the 1 percent level, ** Significant at the 5 percent level, * Significant at the 10 percent level. 


\begin{tabular}{|c|c|c|c|c|c|}
\hline Sample: & Full & $\begin{array}{c}\text { Had sex in past } \\
12 \text { months } \\
\end{array}$ & $\begin{array}{c}\text { Surveyed in } \\
2006-2016\end{array}$ & $\begin{array}{c}\text { Age } 25 \text { and } \\
\text { above }\end{array}$ & Married \\
\hline & Sex in past & Sex in past & Sex in past & Sex in past & Sex in past \\
\hline \multirow[t]{2}{*}{ Dependent variable: } & 7 days & 7 days & 7 days & 7 days & 7 days \\
\hline & $(1)$ & $(2)$ & $(3)$ & $(4)$ & $(5)$ \\
\hline \multicolumn{6}{|l|}{ Panel A: Full sample } \\
\hline Television & $\begin{array}{c}-0.017^{* * *} \\
(0.005)\end{array}$ & $\begin{array}{c}-0.016 * * * \\
(0.005)\end{array}$ & $\begin{array}{c}-0.017^{* * *} \\
(0.005)\end{array}$ & $\begin{array}{c}-0.021^{* * *} \\
(0.007)\end{array}$ & $\begin{array}{c}-0.022^{* * *} \\
(0.007)\end{array}$ \\
\hline Observations & $3,817,006$ & $2,455,564$ & $2,011,505$ & $2,477,333$ & $2,614,945$ \\
\hline Sample mean of dependent variable & 0.30 & 0.47 & 0.34 & 0.36 & 0.42 \\
\hline \multicolumn{6}{|l|}{ Panel B: Females } \\
\hline Television & $\begin{array}{c}-0.017 * * * \\
(0.005)\end{array}$ & $\begin{array}{c}-0.019 * * * \\
(0.004)\end{array}$ & $\begin{array}{c}-0.020^{* * *} \\
(0.005)\end{array}$ & $\begin{array}{c}-0.021^{* * *} \\
(0.006)\end{array}$ & $\begin{array}{c}-0.022 * * * \\
(0.006)\end{array}$ \\
\hline Observations & $3,176,850$ & $2,004,717$ & $1,554,577$ & $2,056,998$ & $2,232,649$ \\
\hline Sample mean of dependent variable & 0.30 & 0.47 & 0.34 & 0.34 & 0.41 \\
\hline \multicolumn{6}{|l|}{ Panel C: Males } \\
\hline Television & $\begin{array}{c}0.000 \\
(0.005)\end{array}$ & $\begin{array}{l}-0.001 \\
(0.008)\end{array}$ & $\begin{array}{l}-0.002 \\
(0.006)\end{array}$ & $\begin{array}{c}0.003 \\
(0.007)\end{array}$ & $\begin{array}{c}0.003 \\
(0.008)\end{array}$ \\
\hline Observations & 640,156 & 450,847 & 456,928 & 420,335 & 382,296 \\
\hline Sample mean of dependent variable & 0.33 & 0.47 & 0.34 & 0.43 & 0.49 \\
\hline Country fixed effects? & YES & YES & YES & YES & YES \\
\hline Survey year fixed effects? & YES & YES & YES & YES & YES \\
\hline Control for total consumer durables? & YES & YES & YES & YES & YES \\
\hline Control for reproductive health knowledge? & YES & YES & YES & YES & YES \\
\hline Additional socio-demographic controls? & YES & YES & YES & YES & YES \\
\hline
\end{tabular}

Notes: Data come from Standard Demographic and Health Surveys (DHS). "Sex in past X days" is an indicator variable. "Television" is an indicator variable. "Additional socio-demographic controls" include the full set of indicator variables for age, married, years of schooling, urban residence, and interview month. Parameters estimated using ordinary least squares (OLS) regression. Robust standard errors in parentheses are clustered at country level. Column 1: repeats Table 2 column 4.

*** Significant at the 1 percent level, ** Significant at the 5 percent level, * Significant at the 10 percent level. 
Appendix Table A1: Countries, Sample Sizes, and Survey Rounds

\begin{tabular}{|c|c|c|}
\hline Country & $\begin{array}{l}\text { Survey } \\
\text { rounds }\end{array}$ & $\begin{array}{c}\text { Sample } \\
\text { size }\end{array}$ \\
\hline Afghanistan & 2015 & 40,149 \\
\hline Albania & 2008 & 10,597 \\
\hline Armenia & 2000, 2005, 2010 & 20,497 \\
\hline Azerbaijan & 2006 & 10,995 \\
\hline Bangladesh & 1993, 1996, 1999, 2004, 2007 & 60,033 \\
\hline Benin & 1996, 2001, 2006, 2011 & 60,295 \\
\hline Bolivia & 1989, 1994, 1998, 2003, 2008 & 77,732 \\
\hline Brazil & $1986,1991,1996$ & 27,672 \\
\hline Burkina Faso & 1993, 1998, 2003, 2010 & 53,873 \\
\hline Burundi & 1987,2010 & 17,609 \\
\hline Cambodia & 2000, 2005, 2010, 2014 & 68,434 \\
\hline Cameroon & 1991, 1998, 2004, 2011 & 45,423 \\
\hline Central African Republic & 1994 & 7,613 \\
\hline Chad & 1996, 2004, 2014 & 40,789 \\
\hline Colombia & 1986, 1990, 1995, 2000, 2005, 2010, 2015 & 193,402 \\
\hline Comoros & 1996,2012 & 10,514 \\
\hline Cote d'Ivoire & 1994, 1998, 2011 & 27,204 \\
\hline Democratic Republic of the Congo & 2007,2013 & 42,125 \\
\hline Dominican Republic & 1991, 1996, 1999, 2002, 2007, 2013 & 84,689 \\
\hline Ecuador & 1987 & 4,713 \\
\hline Egypt & 1988, 1992, 1995, 2000, 2005, 2008, 2014 & 116,001 \\
\hline El Salvador & 1985 & 4,861 \\
\hline Ethiopia & 1992, 1997, 2003 & 68,696 \\
\hline Gabon & 2000,2012 & 22,247 \\
\hline Gambia & 2013 & 10,232 \\
\hline Ghana & 1988, 1993, 1998, 2003, 2008, 2014 & 46,284 \\
\hline Guatemala & 1987, 1995, 1998, 2014, 2015 & 60,635 \\
\hline Guinea & 1999, 2005, 2012 & 28,948 \\
\hline Guyana & 2009 & 8,504 \\
\hline Haiti & 1994, 2000, 2005, 2012 & 45,367 \\
\hline Honduras & 2005, 2011 & 49,885 \\
\hline India & 1992, 1998, 2005, 2015 & 385,780 \\
\hline Indonesia & 1987, 1991, 1994, 1997, 2002, 2007, 2012 & 226,975 \\
\hline Jordan & 1990, 1997, 2002, 2007, 2012 & 50,345 \\
\hline Kazakhstan & 1995, 1999 & 8,570 \\
\hline Kenya & 1989, 1993, 1998, 2003, 2008, 2014 & 93,497 \\
\hline Kyrgyz Republic & 1997,2012 & 14,457 \\
\hline Lesotho & 2004, 2009, 2014 & 30,366 \\
\hline Liberia & 1986, 2007, 2013 & 31,647 \\
\hline Madagascar & 1992, 1997, 2003, 2008 & 47,186 \\
\hline Malawi & 1992, 2000, 2004, 2010, 2015 & 95,085 \\
\hline Maldives & 2009 & 8,611 \\
\hline Mali & 1987, 1995, 2001, 2006, 2012 & 63,283 \\
\hline Mexico & 1987 & 3,401 \\
\hline Moldova & 2005 & 7,439 \\
\hline Morocco & 1987, 1992, 2003 & 32,000 \\
\hline Mozambique & 1997, 2003, 2011 & 43,827 \\
\hline Namibia & 1992, 2000, 2006, 2013 & 41,901 \\
\hline Nepal & 1996, 2001, 2006, 2011, 2016 & 51,399 \\
\hline Nicaragua & 1998,2001 & 29,596 \\
\hline Niger & 1992, 1998, 2006, 2012 & 45,749 \\
\hline Nigeria & 1990, 1999, 2003, 2008, 2013 & 105,961 \\
\hline Nigeria (Ondo State) & 1986 & 4,208 \\
\hline Pakistan & 1990, 2006, 2012 & 34,618 \\
\hline Paraguay & 1990 & 5,819 \\
\hline Peru & $1986,1991,1996,2000,2003-2012$ & 257,120 \\
\hline Republic of the Congo & 2005, 2011 & 23,012 \\
\hline Rwanda & 1992, 2000, 2005, 2010, 2014 & 90,201 \\
\hline Sao Tome and Principe & 2008 & 4,910 \\
\hline Senegal & 1986, 1992, 1997, 1999, 2005, 2010-15 & 89,149 \\
\hline Sierra Leone & 2008, 2013 & 34,499 \\
\hline South Africa & 1998, 2003 & 11,734 \\
\hline Sri Lanka & 1987, 2006 & 5,862 \\
\hline Sudan & 1989 & 5,850 \\
\hline Swaziland & 2006 & 9,114 \\
\hline Tajikistan & 2012 & 9,654 \\
\hline Tanzania & 1991, 1996, 1999, 2004, 2010, 2015 & 69,109 \\
\hline Thailand & 1987 & 6,757 \\
\hline The Philippines & $1993,1998,2003,2008,2013$ & 77,108 \\
\hline Timor-Leste & 2009 & 17,213 \\
\hline Togo & $1988,1998,2013$ & 29,683 \\
\hline Trinidad and Tobago & 1987 & 3,801 \\
\hline Tunisia & 1988 & 4,184 \\
\hline Turkey & $1993,1998,2003$ & 25,099 \\
\hline Uganda & 1988, 1995, 2000, 2006, 2011 & 45,083 \\
\hline Ukraine & 2007 & 10,017 \\
\hline Uzbekistan & 1996 & 4,415 \\
\hline Vietnam & 1997, 2002 & 11,329 \\
\hline Yemen & 1991 & 5,649 \\
\hline Zambia & 1992, 1996, 2001, 2007, 2013 & 69,310 \\
\hline Zimbabwe & 1988, 1994, 1999, 2005, 2010, 2015 & 69,400 \\
\hline Full sample & 1986-2016 & $3,817,000$ \\
\hline
\end{tabular}


Table A2: Trends in Television Ownership and Sexual Activity

\begin{tabular}{|c|c|c|c|}
\hline \multirow[t]{2}{*}{ Interview year: } & Television & Sex in past week & Observations \\
\hline & $(1)$ & $(2)$ & (3) \\
\hline \multicolumn{4}{|c|}{ Panel A: Full sample } \\
\hline 1980-1989 & 0.36 & 0.24 & 136,168 \\
\hline 1990-1999 & 0.38 & 0.25 & 950,340 \\
\hline 2000-2009 & 0.51 & 0.31 & $1,517,642$ \\
\hline 2010-2019 & 0.52 & 0.35 & $1,212,856$ \\
\hline \multicolumn{4}{|c|}{ Panel B: Females } \\
\hline 1980-1989 & 0.36 & 0.24 & 136,168 \\
\hline 1990-1999 & 0.40 & 0.24 & 869,655 \\
\hline 2000-2009 & 0.54 & 0.31 & $1,235,000$ \\
\hline 2010-2019 & 0.54 & 0.35 & 936,027 \\
\hline \multicolumn{4}{|l|}{ Panel C: Males } \\
\hline 1980-1989 & - & - & - \\
\hline 1990-1999 & 0.23 & 0.30 & 80,685 \\
\hline 2000-2009 & 0.42 & 0.30 & 282,642 \\
\hline 2010-2019 & 0.46 & 0.37 & 276,829 \\
\hline \multicolumn{4}{|l|}{ Panel D: Urban } \\
\hline 1980-1989 & 0.57 & 0.22 & 61,232 \\
\hline 1990-1999 & 0.66 & 0.24 & 384,473 \\
\hline 2000-2009 & 0.76 & 0.29 & 682,354 \\
\hline 2010-2019 & 0.79 & 0.32 & 518,689 \\
\hline \multicolumn{4}{|l|}{ Panel E: Rural } \\
\hline 1980-1989 & 0.18 & 0.27 & 74,936 \\
\hline 1990-1999 & 0.20 & 0.25 & 565,867 \\
\hline 2000-2009 & 0.32 & 0.32 & 835,288 \\
\hline 2010-2019 & 0.32 & 0.38 & 694,167 \\
\hline \multicolumn{4}{|c|}{ Panel F: Married } \\
\hline 1980-1989 & 0.35 & 0.31 & 100,818 \\
\hline 1990-1999 & 0.37 & 0.31 & 715,329 \\
\hline 2000-2009 & 0.51 & 0.43 & $1,019,235$ \\
\hline 2010-2019 & 0.50 & 0.51 & 779,563 \\
\hline \multicolumn{4}{|c|}{ Panel G: Not married } \\
\hline 1980-1989 & 0.37 & 0.04 & 35,350 \\
\hline 1990-1999 & 0.43 & 0.06 & 235,011 \\
\hline 2000-2009 & 0.53 & 0.05 & 498,407 \\
\hline 2010-2019 & 0.55 & 0.07 & 433,293 \\
\hline
\end{tabular}

Notes: Data come from Standard Demographic and Health Surveys. Entries in Columns (1) and (2) are sub-sample means. "Television" and "Sex in past week" are indicator variables. 